\title{
Adenosine Release Mediates Cyanide-Induced Suppression of CA1 Neuronal Activity
}

\author{
Ping Jun Zhu and Kresimir Krnjević \\ Anesthesia Research and Physiology Departments, McGill University, Montréal, Québec, Canada H3G 1 Y6
}

The rapid suppression of CNS function produced by cyanide (CN) was studied by field, intracellular, and whole-cell recording in hippocampal slices (at $33-34^{\circ} \mathrm{C}$ ). Population spikes and field EPSPs were depressed by 4-5 min bath applications of 50$100 \mu \mathrm{M}$ CN ( $\left(\mathrm{I}_{50}\right.$ was $18 \mu \mathrm{M}$ for spikes and $72 \mu \mathrm{M}$ for EPSPs). The actions of $\mathrm{CN}$ were reversibly suppressed by the adenosine antagonists 8-sulfophenyltheophylline (8-SPT; $10 \mu \mathrm{M})$ and 8-cyclopentyl-1,3-dipropylxanthine (DPCPX; $0.2 \mu \mathrm{M}$ ), potentiated by the adenosine transport inhibitor dipyridamole $(0.5 \mu \mathrm{M})$, but unaffected by the $\mathrm{K}_{\mathrm{ATP}}$ channel blocker glyburide $(10 \mu \mathrm{M})$. Therefore the $\mathrm{CN}$-induced reductions of synaptic efficacy and postsynaptic excitability - demonstrated by synaptic input:output plots-are mediated mainly by adenosine. In whole-cell or intracellular recordings, CN depressed EPSCs and elicited an increase in input conductance and an outward current, the reversal potential of which was approximately $-90 \mathrm{mV}$ (indi- cating that $\mathrm{K}^{+}$was the major carrier). These effects also were attenuated by 8-SPT. In the presence of $1 \mathrm{~mm} \mathrm{Ba,} \mathrm{CN}$ had no significant postsynaptic action; Cs (2 mm) also prevented CNinduced outward currents but only partly blocked the increase in conductance. Another 8-SPT-sensitive action of CN was to depress hyperpolarization-activated slow inward relaxations $(Q$ current). At room temperature $\left(22-24^{\circ} \mathrm{C}\right)$, although it did not change holding current and slow inward relaxations, $\mathrm{CN}$ raised the input conductance; this effect also was prevented by 8-SPT $(10 \mu \mathrm{M})$, but not by glyburide $(10 \mu \mathrm{M})$. Adenosine release thus appears to be the major link between acute $\mathrm{CN}$ poisoning and early depression of CNS synaptic function.

Key words: adenosine antagonists; $K_{\text {ATP }}$ channel blocker; synaptic transmission; outward current; input conductance; barium; cesium
Cyanide $(\mathrm{CN})$ is a specific inhibitor of cytochrome oxidase, which is essential for mitochondrial ATP production (Keilin, 1930; Isom and Way, 1984). Its use as a suicidal, homicidal, chemical warfare, and genocidal agent is well known. $\mathrm{CN}$ has a characteristically rapid action, especially on the CNS. In cases in which a lethal dose has been administered, it frequently has been noted that the electrical activity of the brain has stopped although the heart is still beating (Bernthal et al., 1928; Dixon and Elliott, 1929; Barcroft, 1931).

$\mathrm{CN}$ quickly but reversibly depresses synaptic transmission in hippocampal slices (Aitken and Braitman, 1989). CN causes a hyperpolarization of some neurons (Biscoe and Duchen, 1989; Duchen, 1990; Cummins et al., 1991; Murphy and Greenfield, 1991; Latha et al., 1994) but sharply depolarizes others (Haddad and Jiang, 1993; Sun and Reis, 1994). The exact links between $\mathrm{CN}$-induced metabolic inhibition and the almost immediate suppression of CNS function remain unclear.

Several authors have suggested that the opening of ATPsensitive $\mathrm{K}$ channels (Noma, 1983) by a fall in $[\mathrm{ATP}]_{\mathrm{i}}$ may explain the depressant action of $\mathrm{CN}$ on various cells (Nichols and Lederer, 1990; Murphy and Greenfield, 1991; Findlay, 1993; Schwanstecher and Panten, 1993).

Received Nov. 16, 1996; revised Dec. 23, 1996; accepted Jan. 22, 1997.

This research was supported financially by the Medical Research Council of Canada and partly by the Fonds pour la Formation de Chercheurs et l'Aide à la

Recherche (Québec). We thank Murray Sweet for his photographic work.

Correspondence should be addressed to Dr. Kresimir Krnjević, McGill University, McIntyre Medical Sciences Building, Room 1208, 3655 Drummond Street, Montréal, Québec, Canada H3G 1Y6.

Dr. Zhu's present address: Departments of Pharmacological and Physiological Sciences, University of St. Louis School of Medicine, 1402 South Grand Boulevard, St. Louis, MO 63104.

Copyright (C) 1997 Society for Neuroscience $0270-6474 / 97 / 172355-10 \$ 05.00 / 0$
On the other hand, adenosine is known to be released in the brain by anoxia and ischemia (Berne et al., 1974; Van Wylen et al., 1986; Richardt et al., 1987, 1994); in some isolated neural preparations, CN suppresses adenosine reuptake and so causes its extracellular accumulation (Thampy and Barnes, 1983; Maire et al., 1984; Kurbat et al., 1993). Adenosine is one of the most potent neuromodulators (Phillis and Wu, 1981; Dunwiddie, 1985; Snyder, 1985; Greene and Haas, 1991): it inhibits neuronal activity by enhancing $\mathrm{K}^{+}$conductance, which causes hyperpolarization (Greene and Haas, 1985; Proctor and Dunwiddie, 1987; Trussell and Jackson, 1987), and by decreasing $\mathrm{Ca}^{2+}$ currents in nerve endings, it reduces transmitter release (Scholz and Miller, 1991; Mogul et al., 1993; Wu and Saggau, 1994). Therefore, adenosine release could be responsible for the nearly immediate loss of synaptic transmission produced by $\mathrm{CN}$-in keeping with the demonstrated involvement of adenosine in the block of synaptic transmission in hippocampal slices produced by other types of energy deprivation, such as anoxia and hypoglycemia (Fowler, 1993; Zhu and Krnjević, 1993, 1997).

In the present experiments we examined the cellular mechanisms of the action of $\mathrm{CN}$ in hippocampal slices. The results provide clear evidence that adenosine is an important mediator of the action of $\mathrm{CN}$ on neuronal activity.

A preliminary report of some of these results has appeared in abstract form (Zhu and Krnjević, 1995).

\section{MATERIALS AND METHODS}

Hippocampal slices from male Sprague Dawley rats were prepared from halothane-anesthetized Sprague Dawley rats (Charles River, Québec, Canada) weighing 110-180 gm. After decapitation, the brain was removed quickly into cold artificial cerebrospinal fluid (ACSF) at $\sim 4^{\circ} \mathrm{C}$, well oxygenated with $95 \% \mathrm{O}_{2} / 5 \% \mathrm{CO}_{2}$ (carbogen). Its composition was 
Figure 1. $\mathrm{CN}$-induced depression of CA1 excitatory synaptic transmission is blocked by an adenosine receptor antagonist. $A, \mathrm{CA} 1$ population spikes were elicited by stimulating stratum radiatum at $0.1 \mathrm{~Hz}$. The initial positive slope reflects the rising phase of the EPSP, and the sharp downward (negative) deflection is the population spike (50\% maximal). Bath application of $100 \mu \mathrm{M} \mathrm{KCN}$ for 5 min reversibly depressed transmission. $B$, Dot plots of CA1 population spike amplitude in another slice. Top, Time course of $\mathrm{CN}$-induced depression. Middle, The action of CN was strongly attenuated by 8-SPT. Bottom, Partial recovery of the action of $\mathrm{CN}$ after washing slice for $60 \mathrm{~min}$. CN superfusion is marked by arrows. $C, D$, Dose-response curves for depression of EPSP $(C)$ and population spike $(D)$; 8-SPT shifted both dose-response curves to the right. One hundred percent represents full suppression of fEPSP and population spikes. $\mathrm{IC}_{50}$ for $\mathrm{CN}$ action is indicated by dashed lines. Data from several experiments were pooled to obtain mean $\pm \operatorname{SEM}(n=5-9)$.
A

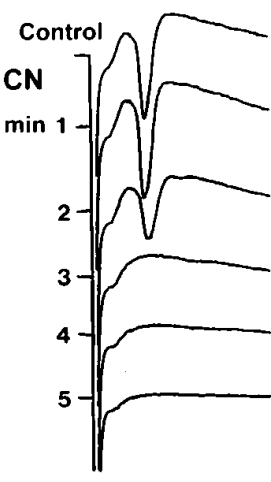

$\min$

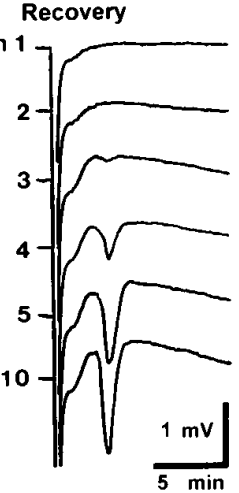

C

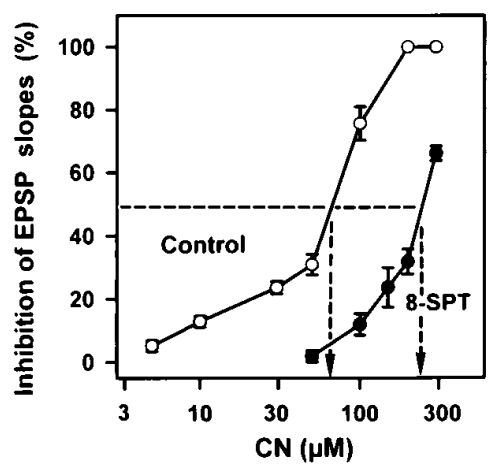

B

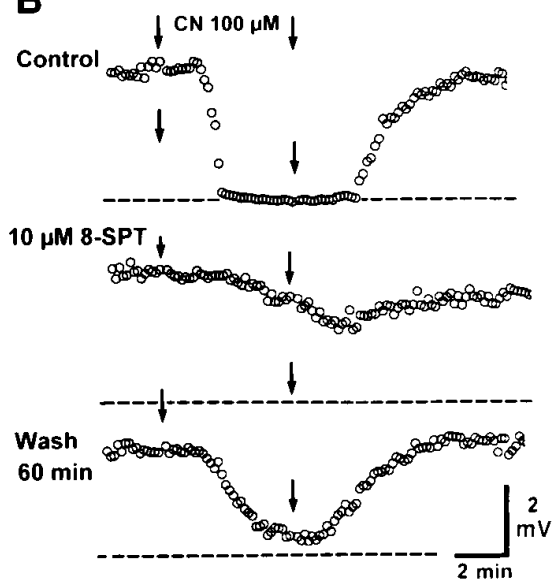

D

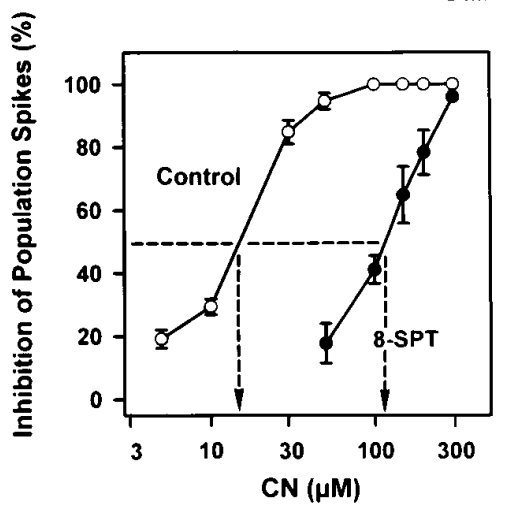

(in mM): $\mathrm{NaCl} 124, \mathrm{KCl} 3, \mathrm{MgCl}_{2} 1.3, \mathrm{CaCl}_{2} 2.0, \mathrm{NaH}_{2} \mathrm{PO}_{4} 1.2$, and glucose 11, $\mathrm{pH}$ 7.3. For all extracellular and some intracellular recordings, 450- $\mu \mathrm{m}$-thick transverse slices were cut with a McIlwain tissue chopper. Especially for whole-cell recordings, $350-400 \mu \mathrm{m}$ slices were cut with a Vibroslice (Campden Instruments, UK). The slices were allowed to recover in carbogenated ACSF at room temperature for $>1 \mathrm{hr}$ before recordings began. All experiments were performed on fully submerged slices kept at $33-34^{\circ} \mathrm{C}$ (Zhu and Krnjević, 1994).

Field recordings were made with $2 \mathrm{M} \mathrm{NaCl}$ electrodes from the CA1 pyramidal layer or stratum radiatum. To evoke synaptic responses, we applied stimuli at $0.1 \mathrm{~Hz}$ through insulated nickel-chromium wires placed in the stratum radiatum. Intracellular recordings were obtained with $3 \mathrm{M} \mathrm{KCl}$ electrodes (70-90 $\mathrm{M} \Omega$ ). Whole-cell recordings were done "blind" (Blanton et al., 1989), with patch pipettes (4-6 M $\Omega$ ) filled with (in mM): $150 \mathrm{KMeSO}_{4}, 10$ HEPES, $2 \mathrm{MgCl}_{2}, 0.1 \mathrm{CaCl}_{2}, 1.1$ EGTA, 2 ATP, and 0.4 GTP. An Axoclamp 2A amplifier (Axon Instruments, Foster City, CA) was used for all experiments, including voltage-clamping in the discontinuous mode, at a switching frequency of $3.5-6.0 \mathrm{kHz}$. The head stage output was monitored continuously to ensure adequate settling in each duty cycle.

Drugs were obtained as follows: kynurenate, bicuculline, and dipyridamole from Sigma (St. Louis, MO); KCN from J. T. Baker (Phillipsburg, NJ); 8-cyclopentyl-1,3-dipropylxanthine (DPCPX) and 8-sulfophenyltheophylline (8-SPT) from Research Biochemicals (Natick, MA); tetrodotoxin (TTX) from the Qinhuangdao Trading Corporation (Qinhuangdao, China). Glyburide was a gift from Hoechst Canada (Montréal, Canada). The data are expressed as mean $\pm \mathrm{SEM}$; whenever possible, differences between means were examined by the paired $t$ test.

\section{RESULTS}

\section{Field recordings}

Figure $1 A$ illustrates the gradual disappearance of field potentials when $100 \mu \mathrm{M} \mathrm{CN}$ was applied for $5 \mathrm{~min}$ : first, population spikes and then fEPSPs. After washout of CN, fEPSPs returned before the population spikes. In 13 slices, $50-100 \mu \mathrm{M} \mathrm{CN}$ fully suppressed population spikes (down by $99 \pm 1.3 \%$ ).

\section{Adenosine antagonists}

To detect a possible role of adenosine in the mechanism of action of $\mathrm{CN}$, we applied the adenosine antagonist 8-SPT (Bruns et al.,
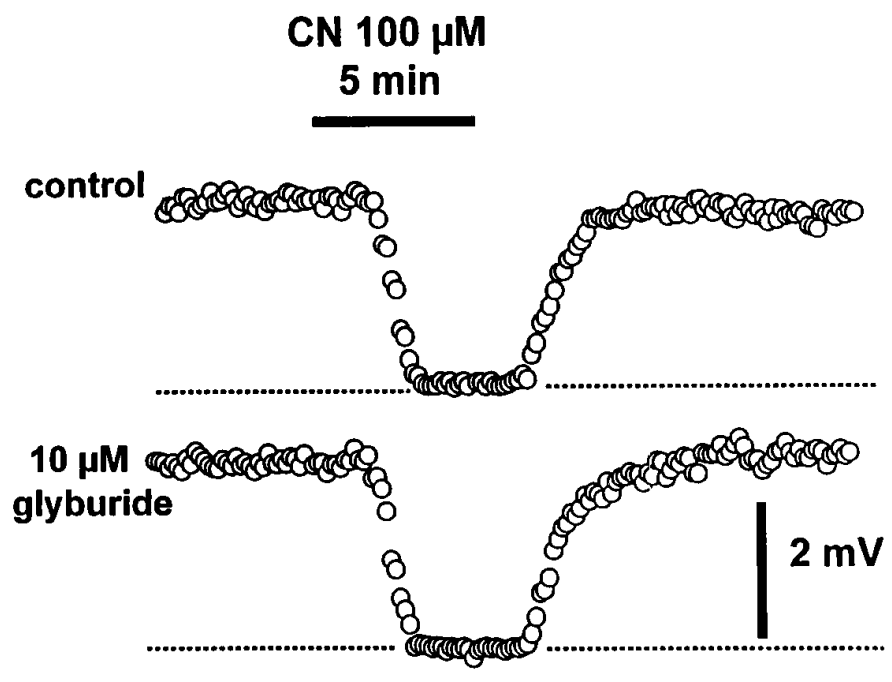

Figure 2. $\mathrm{K}_{\mathrm{ATP}}$ channel blocker did not attenuate $\mathrm{CN}$-induced depression of synaptic transmission. CA1 population spike (50\% maximal) amplitudes are expressed as dot plots. The time of $\mathrm{CN}$ application is indicated by thick horizontal line in $A$. Top, Control run. Bottom, In presence of $\mathrm{K}_{\text {ATP }}$ channel blocker glyburide $(10 \mu \mathrm{M})$. 

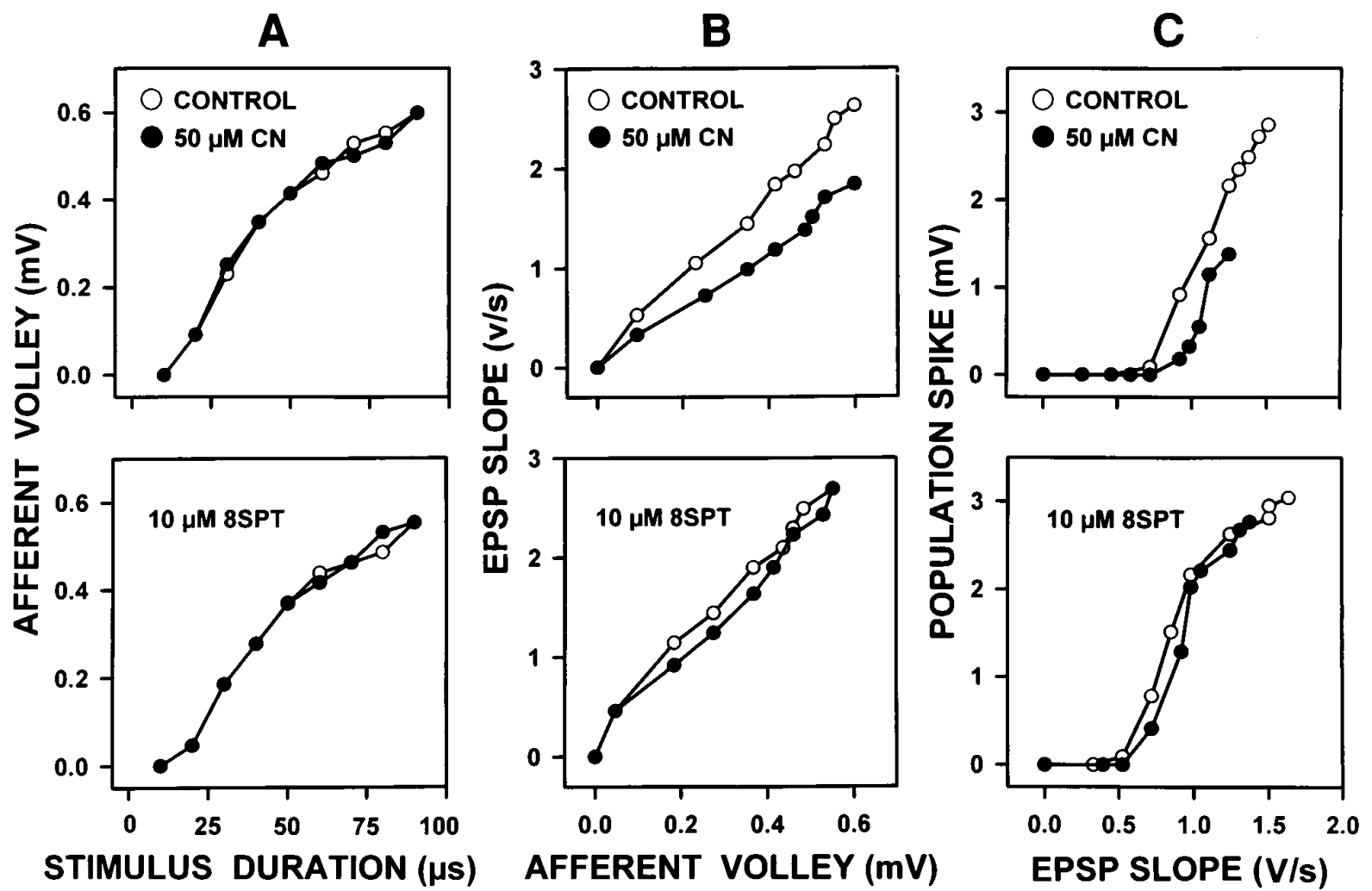

Figure 3. Analysis of the site of $\mathrm{CN}$ action. $A$, Plots of afferent volley (peak-to-peak amplitude) as function of stimulus duration show that neither CN alone (top) nor $\mathrm{CN}$ in presence of 8-SPT (bottom) affects the afferent volley. B, The efficacy of synaptic transmission was examined by plotting the initial rate of rise of EPSPs as function of the size of the afferent volley. Top, CN reduces the slope of the plot and therefore the efficacy of synaptic transmission. Bottom, This effect was nearly abolished by 8-SPT. C, Plots of population spike as function of initial slope of EPSP (E-S coupling). Top, For a given EPSP, $\mathrm{CN}$ decreases corresponding population spike; reduced coupling indicates that $\mathrm{CN}$ also affects postsynaptic mechanisms. Bottom, 8-SPT also attenuated this $\mathrm{CN}$ action. $A$ and $B$ were recorded from CA1 stratum radiatum of same slice. Data in $C$ were recorded from CA1 pyramidal layer of another slice.

Table 1. 8-SPT, Ba, and Cs block increase $(\Delta)$ in input conductance $(\mathrm{nS})$ elicited by $\mathrm{CN}(300 \mu \mathrm{M})$

\begin{tabular}{lccrr} 
& Before CN & \multicolumn{1}{c}{$\Delta$ in CN } & After wash & $n$ \\
\hline Control & $20 \pm 1.8$ & $3.9 \pm 0.52^{* * *}$ & $19 \pm 2.1$ & 16 \\
8-SPT $(10 \mu \mathrm{M})$ & $23 \pm 2.9$ & $0.52 \pm 0.29$ & $22 \pm 2.8$ & 6 \\
Wash & $21 \pm 9.9$ & $3.2 \pm 0.53^{* *}$ & $21 \pm 2.5$ & 6 \\
Control & $20 \pm 5.4$ & $3.4 \pm 0.64^{*}$ & $19 \pm 5.1$ & 3 \\
Ba $(1 \mathrm{mM})$ & $12 \pm 3.2$ & $0.0 \pm 0.003$ & $13.5 \pm 3.1$ & 3 \\
Wash & $15.5 \pm 4.4$ & $2.5 \pm 0.25^{* *}$ & $16 \pm 5.0$ & 3 \\
Control & $20 \pm 2.6$ & $4.1 \pm 0.91^{* *}$ & $20 \pm 2.6$ & 9 \\
Cs $(2 \mathrm{mM})$ & $15 \pm 2.0$ & $1.8 \pm 0.76^{*}$ & $14.5 \pm 1.9$ & 9 \\
Wash & $11 \pm 0.74$ & $2.6 \pm 0.68^{*}$ & $11.5 \pm 0.67$ & 4
\end{tabular}

Data were obtained by intracellular recording with $3 \mathrm{M} \mathrm{KCl}$ electrodes at $34^{\circ} \mathrm{C} ; n$ is number of cells tested. ${ }^{* * *} p<0.001,{ }^{* *} p<0.01$, and ${ }^{*} p<0.05$, all paired $t$ tests.

1980). As shown in Figure $1 B$, the $\mathrm{CN}$-induced depression was attenuated markedly $(n=25)$ : in $10 \mu \mathrm{M} 8-\mathrm{SPT}, 50 \mu \mathrm{M} \mathrm{CN}$ reduced population spikes by only $14 \pm 8.4 \%(n=5)$ and $100 \mu \mathrm{M} \mathrm{CN}$ by $41 \pm 4.4 \%(n=8)$; these effects of 8-SPT were readily reversible. The dose-response curves for $\mathrm{CN}$ thus were shifted to the right by 8-SPT (Fig. $1 C, D$ ): $\mathrm{IC}_{50}$ values for the action of $\mathrm{CN}$ on fEPSPs and population spikes were 72 and $18 \mu \mathrm{M}$, respectively, under control conditions and $\sim 4$ times higher, 254 and $85 \mu \mathrm{M}$, in the presence of $10 \mu \mathrm{M}$ 8-SPT. A more selective $\mathrm{A}_{1}$ adenosine antagonist, DPCPX (Bruns et al., 1987), had a similar action: in $200 \mathrm{nM}$
DPCPX, $100 \mu \mathrm{M}$ CN depressed population spikes by only $51 \pm$ $2.5 \%(n=5)$.

\section{Adenosine transport block}

We also looked at the effect of dipyridamole, which raises extracellular levels of adenosine by blocking adenosine transport (Young and Jarvis, 1983; Phillis et al., 1989). Bath applications of dipyridamole $(0.5 \mu \mathrm{M})$ did not delay the block of population spikes (half-block time was $139 \pm 6.4 \mathrm{sec}$ in control runs and $138 \pm 5.4 \mathrm{sec}$ in the presence of $0.5 \mu \mathrm{M}$ dipyridamole), but they delayed significantly the recovery of population spikes after the end of $\mathrm{CN}$ applications (by $47 \pm 10 \%$, for $n=6, p<0.01$, from the control value of $199 \pm 1.6 \mathrm{sec})$, thus confirming a significant involvement of adenosine.

\section{$K_{\text {ATP }}$ channel block}

Because $\mathrm{CN}$ blocks ATP synthesis, we considered whether $\mathrm{CN}$ might act by opening ATP-sensitive $\mathrm{K}\left(\mathrm{K}_{\mathrm{ATP}}\right)$ channels. This could depress synaptic transmission by hyperpolarizing either preor postsynaptic elements (or both). In six slices, however, the specific blocker of $\mathrm{K}_{\mathrm{ATP}}$ channels, glyburide $(10 \mu \mathrm{M})$, did not prevent the depression of EPSPs by CN (Fig. 2). The mean times to half-block (from the start of the application of $\mathrm{CN}$ ) and half-recovery (after its end) were $127 \pm 13.5$ and $186 \pm 14.6 \mathrm{sec}$, respectively, in control runs; in the presence of $10 \mu \mathrm{M}$ glyburide, they were virtually identical, $133 \pm 10.4$ and $191 \pm 14.0 \mathrm{sec}$, respectively. 
A

\section{$\mathrm{CN} 300 \mu \mathrm{M}$}

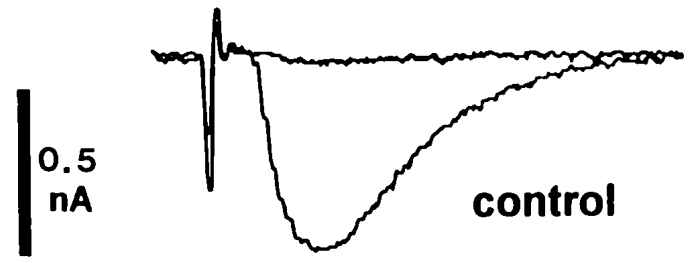

B

\section{8-SPT $10 \mu \mathrm{M}$}

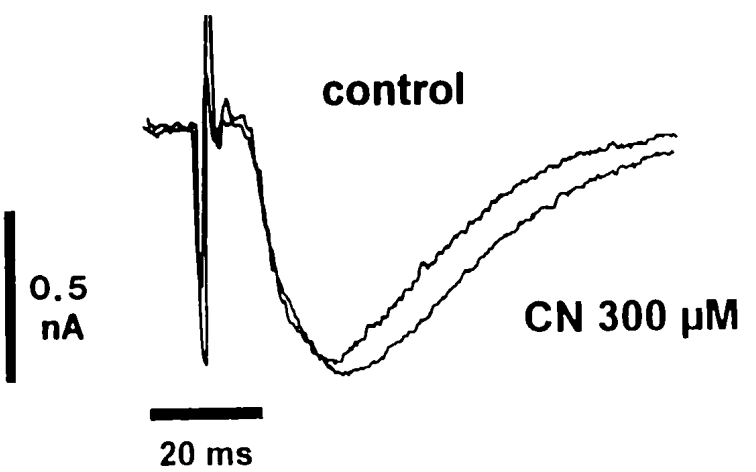

Figure 4. 8-SPT prevents CN-induced suppression of EPSCs. In whole-cell recording from a CA1 neuron, EPSCs were elicited by stimulation of stratum radiatum at $0.1 \mathrm{~Hz}$. Membrane potential was held at $-70 \mathrm{mV}$ throughout. $A$, Control run. $B$, From same neuron in presence of 8-SPT $(10 \mu \mathrm{M})$.

\section{Synaptic sites of $\mathrm{CN}$ action}

To identify the site of $\mathrm{CN}$ action, we looked for selective changes in the afferent volley (the compound action potential of afferent axons), EPSP and population spike. In Figure $3 A$ the peak-topeak amplitude of the afferent volley is plotted as function of stimulus strength: the lack of effect of $\mathrm{CN}$ shows that $\mathrm{CN}$ did not alter axonal excitability.

The efficacy of synaptic transmission was assessed by plotting the initial rate of rise of fEPSPs as function of afferent volley size (Fig. 3B); $50 \mu \mathrm{M} \mathrm{CN}$, applied for $5 \mathrm{~min}$, reduced the slope of such plots by $18 \pm 3.5 \%$ (for $n=5, p<0.01$ ). This effect was prevented by 8 -SPT (in the bottom plots of Fig. $3 B$, CN changed the slopes by only $2 \pm 1.4 \%, n=5$ ).

A possible postsynaptic action was investigated by plotting population spike amplitude as function of EPSP rate of rise (Fig. $3 C$ ). This "E-S relation" is an index of the ability of EPSPs to generate action potentials (Andersen et al., 1980). As shown by the top plots of Figure $3 C$, in the presence of CN EPSPs consistently generated smaller population spikes. In five slices, the mean reduction (estimated by comparing the areas under plots) was by $57 \pm 10.9 \%(p<0.01)$, but in the presence of 8 -SPT CN produced no significant change $(-1.9 \pm 4.5 \%, n=5$; bottom plots in Fig. 3C). Judging by these data, the depression of transmission induced by a brief $\mathrm{CN}$ application-apparently affecting both synaptic efficacy and E-S coupling-is caused mainly by adenosine.

\section{Whole-cell and intracellular recordings}

The effect of $\mathrm{CN}$ on synaptic transmission was examined further by whole-cell recording under voltage clamp. As shown in Figure $4 A, 300 \mu \mathrm{M} C N$ nearly abolished EPSCs elicited by stimulation of stratum radiatum. In nine neurons, 3-4 min applications of $\mathrm{CN}$

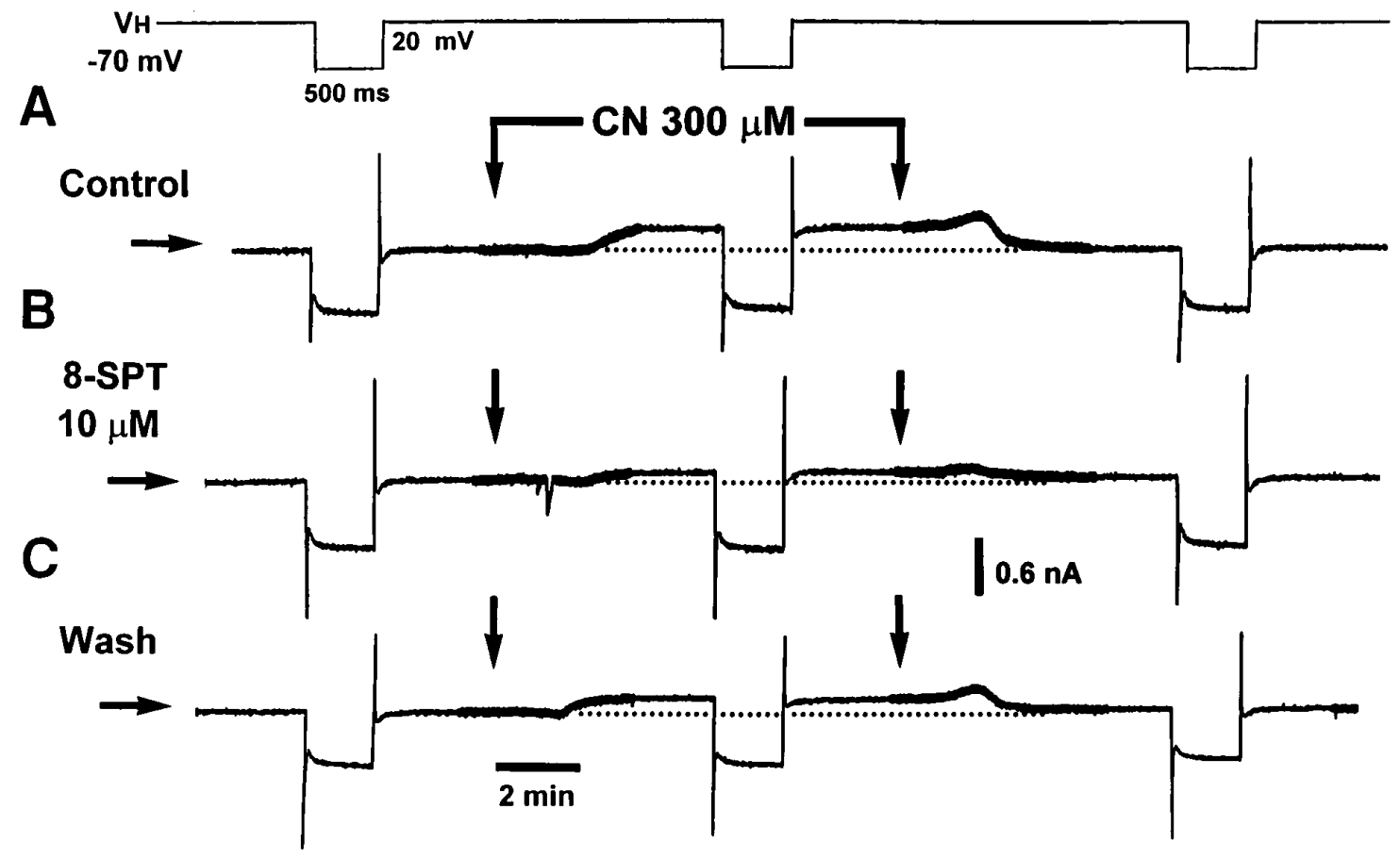

Figure 5. Adenosine mediates outward current and increase in input conductance elicited by $\mathrm{CN}$. Intracellular recording (with $3 \mathrm{M} \mathrm{KCl} \mathrm{electrode)} \mathrm{was}$ from a CA1 neuron under voltage clamp in the presence of $0.5 \mu \mathrm{M}$ TTX. Transmitter-mediated responses were minimized further by 2 mM kynurenate and $10 \mu \mathrm{M}$ bicuculline. Hyperpolarizing pulses $(-20 \mathrm{mV}, 500 \mathrm{msec}-$ monitored on topmost trace $)$ and corresponding currents are shown on expanded time scale before, during, and after $\mathrm{CN}$ application. Zero current levels are indicated by horizontal arrows, at left of traces. Note substantial outward current, as well as increased conductance $(A)$, which was blocked by 8 -SPT $(B) . C$ was recorded after 45 min wash. 

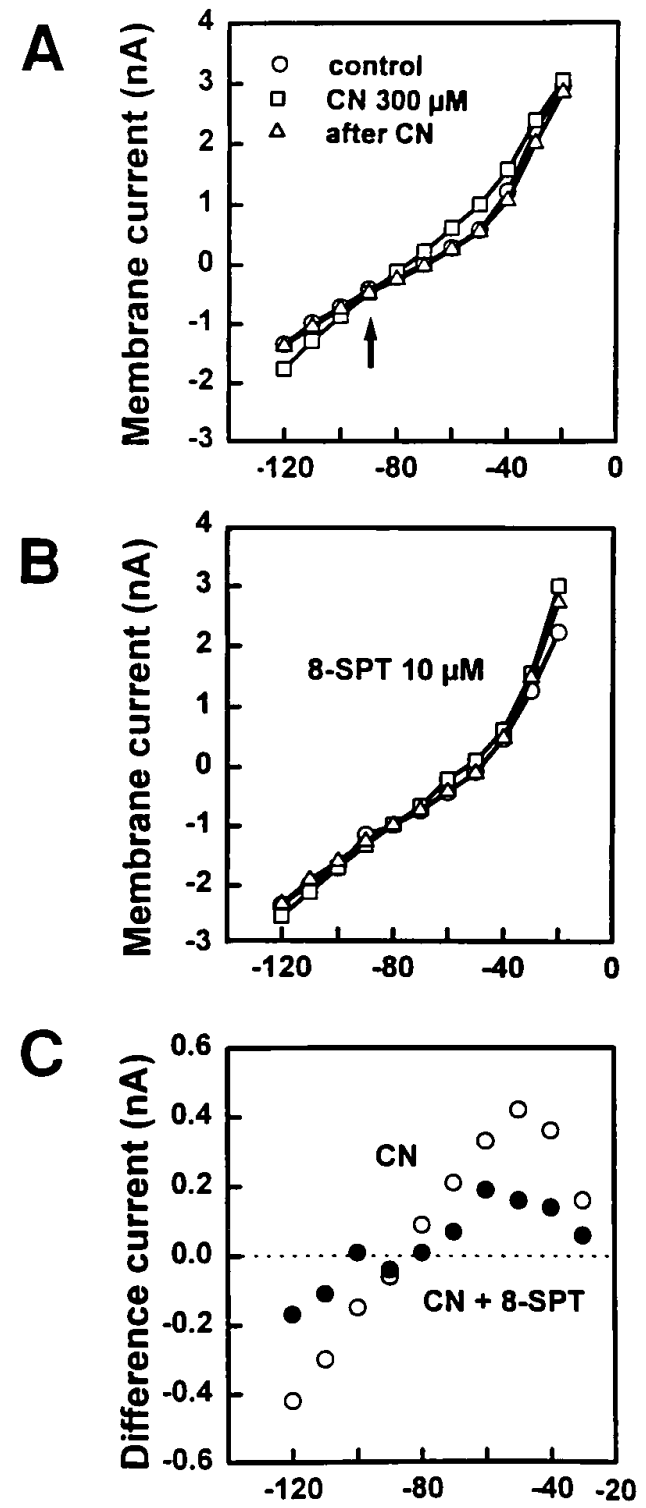

\section{Membrane potential (mV)}

Figure 6. Voltage dependence of $\mathrm{CN}$-induced current, from cell illustrated in Figure 5. A, Data obtained before, during, and after $\mathrm{CN}$ application; note intersection of control and test plots near $-90 \mathrm{mV}$ (indicated by arrow). $B$, The action of $\mathrm{CN}$ was strongly attenuated by 8 -SPT. $C$, Difference currents-obtained by subtracting control values of currents (before $\mathrm{CN}$ application) from currents recorded in presence of $\mathrm{CN}-$ are the currents activated by the action of $\mathrm{CN}$. Note that relatively large $\mathrm{CN}$ difference current (open circles) was much reduced by 8-SPT (closed circles).

(200-300 $\mu \mathrm{M})$ reduced EPSCs by $94 \pm 3.1 \%$ from control values of $0.39 \pm 0.03 \mathrm{nA}$, at $V_{\mathrm{H}}-70 \mathrm{mV}$. In the presence of $10 \mu \mathrm{M}$ 8-SPT, CN was far less effective (Fig. 4B), depressing EPSCs by only $21 \pm 11.6 \%(p>0.10)$ from control values of $0.44 \pm 0.07 \mathrm{nA}$ $(n=4)$.

\section{Postsynaptic changes}

In voltage-clamp recordings with intracellular $(3 \mathrm{M} \mathrm{KCl})$ electrodes (Fig. $5 A$ ), at $V_{\mathrm{H}}$ approximately $-70 \mathrm{mV}, \mathrm{CN}$ elicited very substantial outward currents $(176 \pm 4.0 \mathrm{pA})$ and increased $\mathrm{G}_{\mathrm{N}}$ by
$20 \pm 2.6 \%(p<0.001, n=16)$ from control values of $20 \pm 1.8 \mathrm{nS}$. Both outward current and conductance rise were reduced by 10 $\mu \mathrm{M}$ 8-SPT (Fig. $5 B$ ). In the presence of 8 -SPT, $\mathrm{CN}$ elicited a nonsignificant inward current of $35 \pm 18 \mathrm{pA}$, and $\mathrm{G}_{\mathrm{N}}$ rose by only $2.2 \pm 1.3 \%(p>0.10)$-from $23 \pm 2.9 \mathrm{nS}(n=6)$ (Table 1$)$. The voltage dependence of $\mathrm{CN}$ action is shown by the current-voltage plots of Figure 6: note the reversal potential near $-90 \mathrm{mV}$ (arrow in Fig. 6A). The difference current evoked by $\mathrm{CN}$ is plotted in Figure $6 C$ (open circles). Its reversal at $-90 \pm 2.2 \mathrm{mV}$ indicates that $\mathrm{CN}$ probably activates a $\mathrm{K}$ conductance.

As observed with hypoxia (Zhang and Krnjević, 1993), the postsynaptic effects of $\mathrm{CN}$ were much smaller in whole-cell recordings: at $V_{\mathrm{H}}-55 \mathrm{mV}, \mathrm{CN}$ elicited an outward current of only $80 \pm 8.2 \mathrm{pA}$, accompanied by a just significant increase in $\mathrm{G}_{\mathrm{N}}(6 \pm$ $2.9 \% ; p=0.05)$ from a low control level of $12 \pm 1.0 \mathrm{nS}(n=15)$. In the presence of 8-SPT, CN evoked an inward current of $16 \pm$ $3.9 \mathrm{nA}$, accompanied by a nonsignificant $2 \pm 2.5 \%$ decrease in input conductance from control values of $13 \pm 1.0 \mathrm{nS}$ (for $n=12$ ). All of these data suggest that adenosine release is a major component of the mechanism of action of $\mathrm{CN}$, which reduces postsynaptic excitability by activating $\mathrm{K}$ channels.

In general, lowering the temperature greatly reduced the effects of CN (like those of hypoxia; Hochachka and Mommsen, 1983; Morris et al., 1991). Nevertheless, $\mathrm{CN}$ increased the input conductance (Fig. $7 a, b$ ) even in slices kept at $22-24^{\circ} \mathrm{C}$. In seven whole-cell recordings at $V_{\mathrm{H}}-50 \mathrm{mV}$, applications of $300 \mu \mathrm{M} \mathrm{CN}$ raised $\mathrm{G}_{\mathrm{N}}$ by $3.7 \pm 1.04 \mathrm{nS}(p<0.01$; from $10 \pm 2.1 \mathrm{nS})$, but the holding current did not change significantly (by $12 \pm 12.1 \mathrm{pA}$, from the control level of $69 \pm 16.1 \mathrm{pA}$ ) - mainly because of the marked positive shift in reversal potential for the action of $\mathrm{CN}$ (at arrow in Fig. 7a), presumably because of the corresponding shift in $E_{\mathrm{K}}$ or the activation of other ionic channels. At room temperature, glyburide (Fig. $7 c, d$ ) again failed to prevent the $\mathrm{CN}$-induced rise in $\mathrm{G}_{\mathrm{N}}$ (by $4.7 \pm 0.85 \mathrm{nS}, p<0.005, n=6$; from a control value of $7.5 \pm 0.70 \mathrm{nS})$. These data further support the conclusion that $\mathrm{K}_{\mathrm{ATP}}$ channels do not contribute significantly to $\mathrm{CN}$-induced responses of CA1 neurons. As before, $10 \mu \mathrm{M}$ 8-SPT abolished the effect of $\mathrm{CN}$ (Fig. 7e,f), $\mathrm{G}_{\mathrm{N}}$ increasing by only $0.3 \pm 1.65 \mathrm{nS}(n=$ 6) from a control value of $5.5 \pm 0.40 \mathrm{nS}$.

\section{Barium and cesium}

Both $\mathrm{Ba}(1 \mathrm{~mm})$ and $\mathrm{Cs}(2 \mathrm{~mm})$ attenuated the postsynaptic action of $\mathrm{CN}$. As a potent blocker of a variety of $\mathrm{K}$ channels, Ba can be expected to be an antagonist of $\mathrm{CN}$. Indeed, Ba (1-2 mM) strongly suppressed $\mathrm{CN}$-induced changes in holding current and $\mathrm{G}_{\mathrm{N}}$, as shown in Figure 8. In three cells held at approximately $-70 \mathrm{mV}$ (intracellular recording), Ba (1 mM) abolished the outward currents elicited by $\mathrm{CN}(113 \pm 37 \mathrm{pA})$, replacing them by small inward currents $(1.3 \pm 0.64 \mathrm{pA})$. The $\mathrm{CN}$-induced increase in $\mathrm{G}_{\mathrm{N}}$ also was fully blocked by $\mathrm{Ba}(n=3)$ (Table 1$)$. Similar results were obtained in whole-cell recordings (with $V_{\mathrm{H}}$ approximately -55 $\mathrm{mV})$ : in $1 \mathrm{~mm} \mathrm{Ba}, \mathrm{CN}(300 \mu \mathrm{M})$ elicited no significant shift in base line current $(-1.4 \pm 5.14 \mathrm{pA}, n=8)$ from the control base line of $-14 \pm 6.8 \mathrm{pA}$ and had no effect on $\mathrm{G}_{\mathrm{N}}(0.8 \pm 5.4 \%$ increase from $8.6 \pm 0.46 \mathrm{nS}, n=8$ ).

More surprising was the finding that $\mathrm{Cs}(2 \mathrm{~mm})$ also diminished the outward currents elicited by $\mathrm{CN}$, both in whole-cell and intracellular recordings (Fig. 9). In nine control intracellular recordings, $\mathrm{CN}(300 \mu \mathrm{M})$ evoked outward currents of $80 \pm 15.5 \mathrm{pA}$ $(p<0.001)$; after adding $2 \mathrm{~mm} \mathrm{Cs}$, they were replaced by nonsignificant inward currents of $13 \pm 8.1 \mathrm{pA}$. However, Cs did not fully suppress $\mathrm{CN}$-induced increases in input conductance 


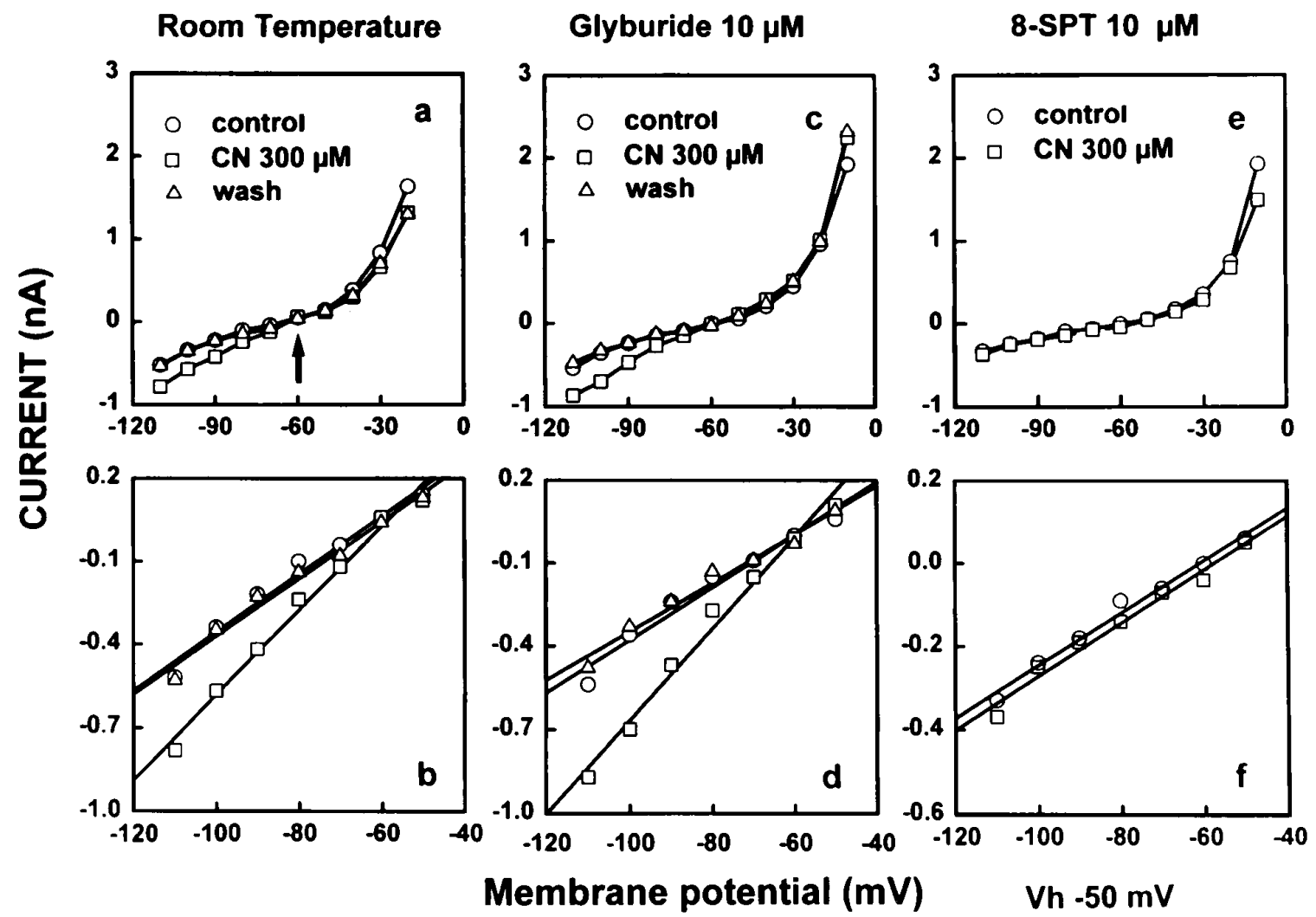

Figure 7. Current-voltage plots illustrate the action of $\mathrm{CN}$ at room temperature. Data are from whole-cell recordings. Linear portions of $I-V$ relations are shown expanded in bottom panels. Open circles, squares, and triangles are data obtained before, during, and after CN application, respectively. Note relatively positive reversal potentials. $\mathrm{CN}$ increased input conductance $(a, b)$; in $10 \mu \mathrm{M}$ glyburide, the action of $\mathrm{CN}$ on conductance was even enhanced $(c, d)$. In $e$ and $f, 8$-SPT blocked the action of CN. For further details, see text.

Figure 8. Ba blocks $\mathrm{CN}$-induced outward current and reduces input conductance change. Intracellular recording was from CA1 neuron under voltage clamp in presence of $0.5 \mu \mathrm{M}$ TTX, $1 \mathrm{~mm}$ kynurenate, and $10 \mu \mathrm{M}$ bicuculline. As in Figure 5, traces were accelerated at intervals for better display of currents evoked by hyperpolarizing pulses (monitored in topmost trace), and zero current levels are indicated by horizontal arrows at left. $\mathrm{CN}$-induced outward current and increase in input conductance $(A)$ were blocked by $1 \mathrm{~mm}$ Ba $(B)$. Trace in $C$ shows partial recovery after wash.

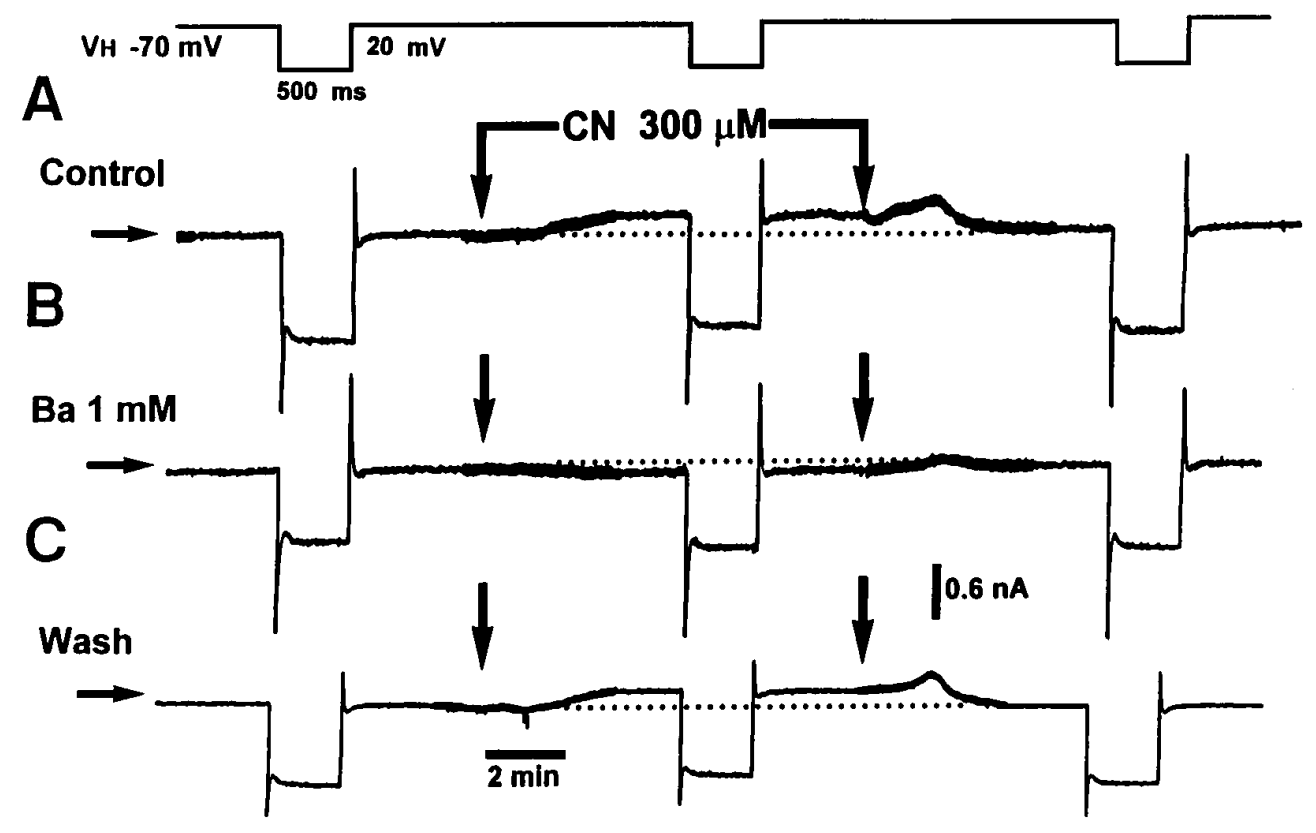

(Table 1). These results suggest that part of the action of $\mathrm{CN}$ is mediated by block of the hyperpolarization-activated inward current $\left(I_{\mathrm{Q}}\right)$ (Maccaferri et al., 1993; Perkins and Wong, 1995). Indeed, $300 \mu \mathrm{M} \mathrm{CN}$ sharply reduced $I_{\mathrm{Q}}$-like slow inward relaxations seen during hyperpolarizing pulses (Fig. 10A). Such data from six neurons are plotted as a function of membrane potential in the left panel of Figure $10 \mathrm{~B}$. The suppression of this effect of $\mathrm{CN}$ by 8 -SPT (Fig. 10, right panels) is in agreement with previous reports that adenosine reduces $I_{\mathrm{h}}$ in geniculocortical neurons (Pape, 1993) and mesopontine cholinergic neurons (Rainnie et al., 1994). It provides further evidence that adenosine is the principal mediator of the actions of $\mathrm{CN}$ on membrane currents. 


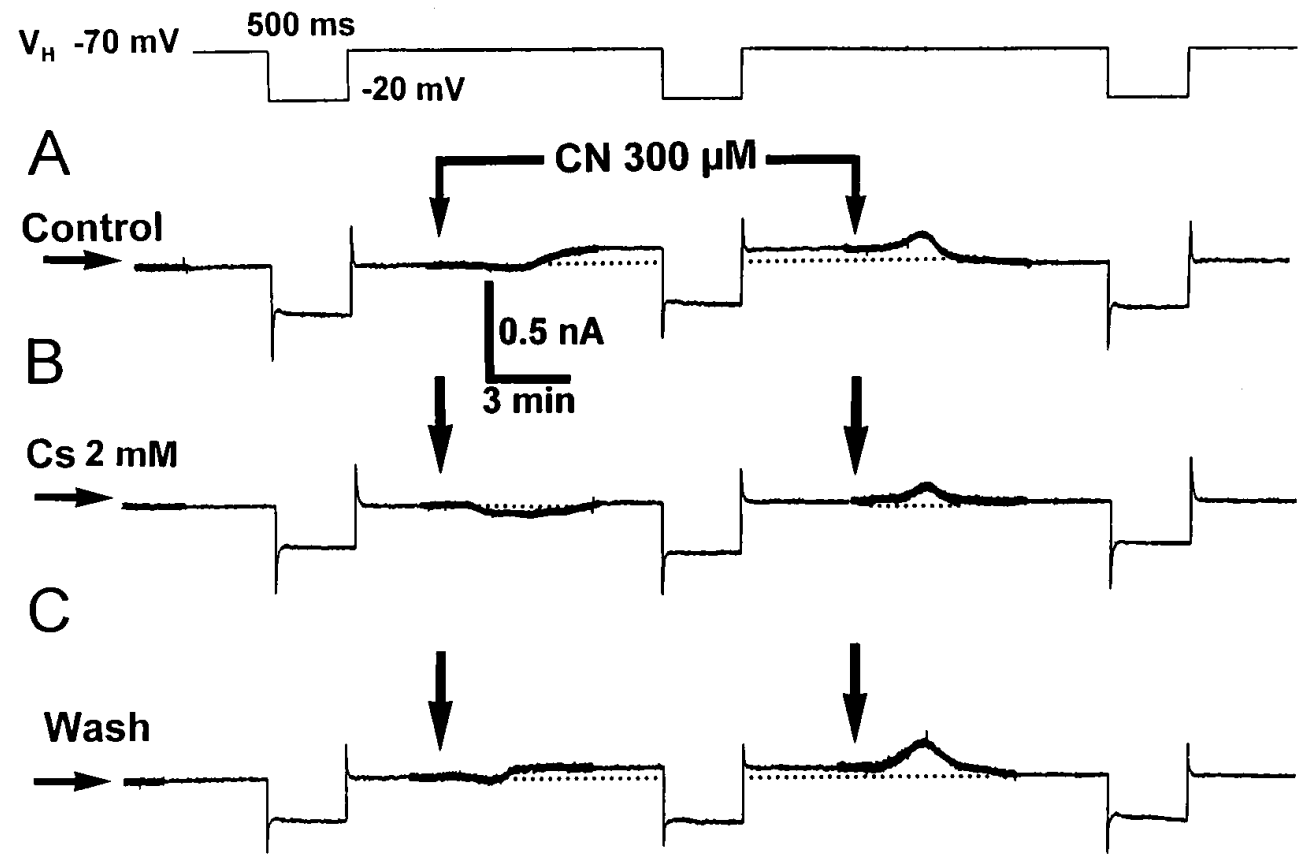

Figure 9. $\mathrm{CN}$-induced outward current also is attenuated by Cs. Arrangement as in Figures 5 and 8: outward current $(A)$ was blocked by $2 \mathrm{~mm}$ Cs $(B)$. Trace in $C$ shows partial recovery of the effects of $\mathrm{CN}$ after wash. As before, zero current levels are indicated by horizontal arrows at left. Note that $\mathrm{Cs}$ did not fully prevent $\mathrm{CN}$ induced increase in input conductance.

A
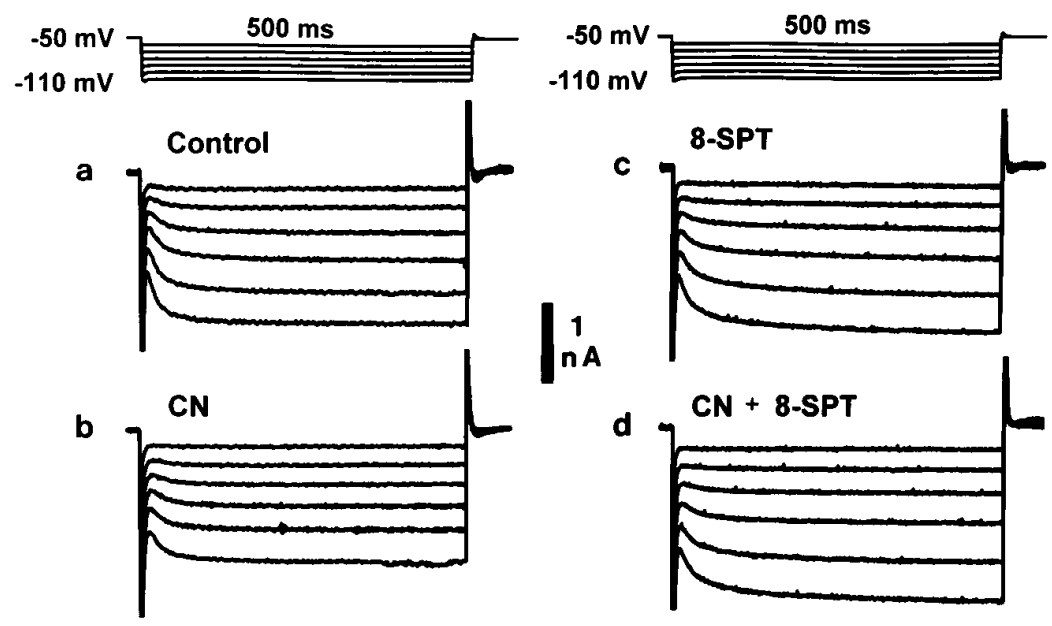

B
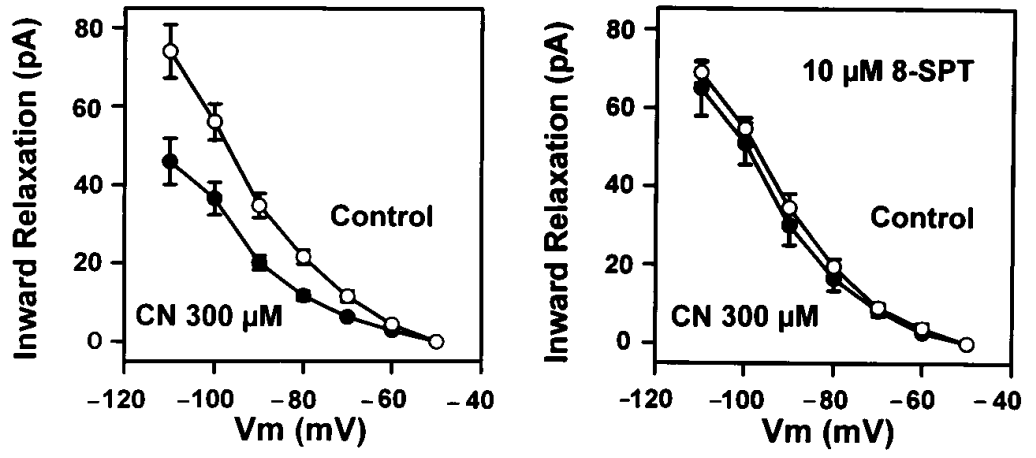

Figure 10. Adenosine antagonist 8-SPT attenuated $\mathrm{CN}$-induced depression of Q-like current. $A$, Wholecell recordings of slow inward relaxations during hyperpolarizing pulses (Q-like current) $(a)$, their depression by $300 \mu \mathrm{M} \mathrm{CN}(b)$, and block of this effect by 8-SPT $(c, d)$. Slow inward relaxations-evoked by $500 \mathrm{msec}$ hyperpolarizing voltage steps $(-10$ to -60 $\mathrm{mV}$, from $V_{\mathrm{H}}-50 \mathrm{mV}$ )-were measured by subtracting instantaneous current from steady-state current for each trace. $B$, Current-voltage relations of inward relaxations before (open circles) and during $\mathrm{CN}$ applications (closed circles). Left, Control runs $(n=6)$; right, $\mathrm{CN}$ had little effect in presence of 10 $\mu \mathrm{M}$ 8-SPT $(n=5)$.

Cooling the slices to $22-24^{\circ} \mathrm{C}$ prevented the $\mathrm{CN}$-induced depression of the inward relaxations (Fig. $11 ; n=6$ ), perhaps owing to reduction of adenosine release. Thus, the postsynaptic hyperpolarizing effect of $\mathrm{CN}$ appears to be mediated partly by an increase in $\mathrm{G}_{\mathrm{N}}$ (presumably mainly a $\mathrm{K}$ conductance) and partly by depression of an $I_{\mathrm{Q}}$-like inward current.

\section{DISCUSSION}

The present results confirm an earlier report that $\mathrm{CN}$ reversibly suppresses synaptic transmission in CA1 (Aitken and Braitman, 1989). In addition, they show that the action of $\mathrm{CN}$ is reduced greatly by DPCPX or 8-SPT and enhanced by dipyridamole and, therefore, principally caused by adenosine release. The 
Room Temperature

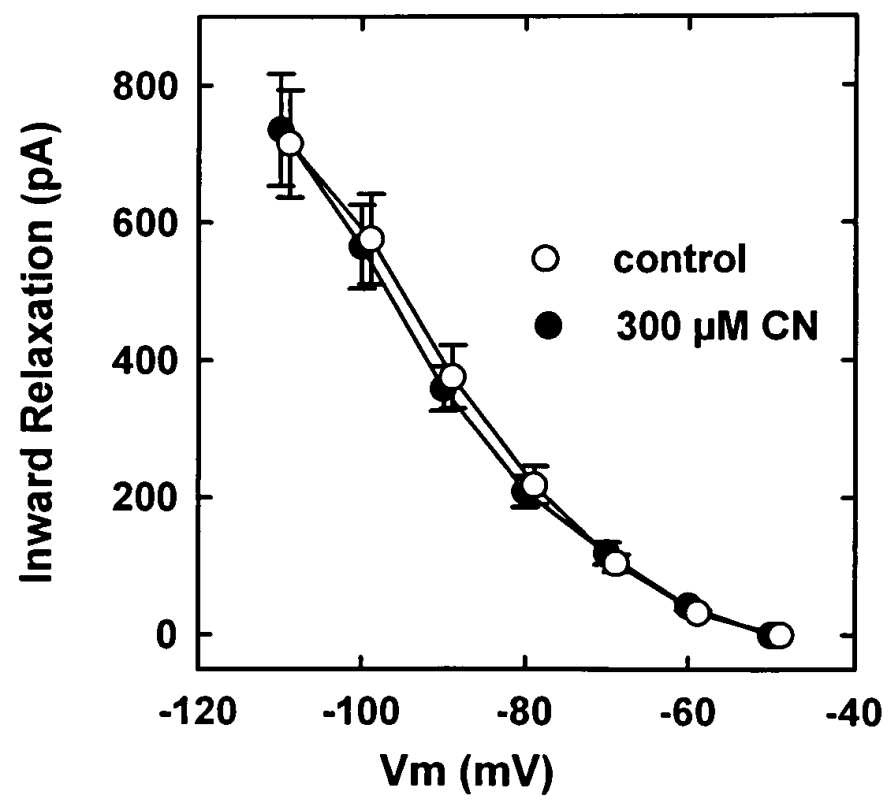

Figure 11. $\mathrm{CN}$ did not significantly depress hyperpolarization-activated Q-like current at room temperature $\left(22-24^{\circ} \mathrm{C}\right)$. Slow inward relaxations were evoked as in Figure 10. Shown is voltage dependence of inward relaxation before (open circles) and during $\mathrm{CN}$ application (closed circles); $n=6$.

adenosine-mediated depression of EPSPs is mainly attributable to the block of glutamate release (Phillis and Wu, 1981; Dunwiddie, 1985; Snyder, 1985; Greene and Haas, 1991). Precisely how adenosine acts on nerve endings is not yet certain. Are the terminal $\mathrm{Ca}^{2+}$ currents affected directly or as a result of $\mathrm{G}_{\mathrm{K}}$ increase? There is also reason to believe that ATP is essential for glutamate release (Nicholls, 1989), which thus could be depressed by even minor depletions of ATP-such as those observed during hypoxia in areas rich in synapses (Lipton and Whittingham, 1982). However, in view of the striking protective effect of the adenosine antagonists, it seems that adenosine must be the principal agent responsible for the block of EPSPs.

There had been no previous reports of membrane effects of $\mathrm{CN}$ on CA1 neurons in slices. Studies on other neurons revealed a variety of effects, apparently not because of adenosine. Thus, both in the spinal cord and brainstem, $\mathrm{CN}$ has a sharp excitatory and depolarizing action (Godfraind et al., 1971; Haddad and Jiang, 1993; Sun and Reis, 1994) - explained by a rapid activation of $\mathrm{Na}$ or $\mathrm{Ca}$ currents and quite unlike the hyperpolarizing effect of adenosine on the same cells (Sun and Reis, 1994). By contrast, Murphy and Greenfield (1991) and Trapp and Ballanyi (1995) observed hyperpolarizing effects on neurons in substantia nigra and dorsal vagal nucleus, respectively, which they ascribed to activation of $\mathrm{K}_{\mathrm{ATP}}$ channels, caused by depletion of ATP.

In the present experiments on slices, the hyperpolarizing effect was like that seen in acutely dissociated hippocampal neurons (Cummins et al., 1991). It proved to be quite insensitive to glyburide and so unlikely to be mediated by $\mathrm{K}_{\mathrm{ATP}}$ channels, but it was very much reduced by adenosine $A_{1}$ antagonists: the activation of $A_{1}$ receptors must, therefore, play an essential role in the underlying mechanism. This should not be surprising, because $\mathrm{CN}$ is known to release adenosine from nerve cells (Maire et al., 1984; Kurbat et al., 1993), and adenosine has a well known hyperpolar- izing effect on hippocampal neurons, produced by a relatively direct-only G-protein-mediated-enhancement of $\mathrm{G}_{\mathrm{K}}$ (Greene and Haas, 1985; Trussell and Jackson, 1987).

But why does $\mathrm{CN}$ not have the same effect on neurons in other parts of the brain? Moreover, one would expect the hyperpolarizing action of conventional hypoxia to have a similar mechanism. So far, there has been little evidence that the hyperpolarization (as opposed to the synaptic block) produced in slices by hypoxia is caused by adenosine (Leblond and Krnjević, 1989; Spuler and Grafe, 1989) (but cf. Zhu and Krnjević, 1997).

One must, therefore, consider some alternative hyperpolarizing mechanism. It is well known that $\mathrm{CN}$ raises cytoplasmic free $\mathrm{Ca}^{2+}$ in a variety of cells-including several types of neurons (Biscoe and Duchen, 1990; Duchen et al., 1990; Dubinsky and Rothman, 1991; Duchen and Biscoe, 1992; Kaplin et al., 1996), as well as glia (Brismar and Collins, 1993), vascular smooth muscle (Miller et al., 1993), and chromaffin cells (Latha et al., 1994). CN thus could produce hyperpolarization by activating a $\mathrm{Ca}^{2+}$-sensitive $\mathrm{G}_{\mathrm{K}}$ $\left(\mathrm{G}_{\mathrm{K}(\mathrm{Ca})}\right)$. There is, indeed, evidence that hypoxic hyperpolarizations are caused by $\mathrm{Ca}^{2+}$ release from an $\mathrm{IP}_{3}$-dependent store (Belousov et al., 1995), likely initiated by glycolytically produced nicotinamide adenine dinucleotide (NADH) (Kaplin et al., 1996).

Are these mechanisms mutually exclusive? Not necessarily. In several kinds of cells adenosine, acting via $\mathrm{A}_{1}$ receptors, triggers the formation of $\mathrm{IP}_{3}$ (Arend et al., 1988; Kohl et al., 1990; Gerwins and Fredholm, 1992). This $\mathrm{IP}_{3}$ may be essential for the action of NADH, because NADH acts by sensitizing $\mathrm{IP}_{3}$ receptors (Kaplin et al., 1996). Thus, a synergistic convergence of two effects of $\mathrm{CN}$, enhanced glycolysis and adenosine release, may be necessary to raise $\left[\mathrm{Ca}^{2+}\right]$ sufficiently to activate $\mathrm{G}_{\mathrm{K}(\mathrm{Ca})}$. In keeping with such a mechanism, adenosine increases slow afterhyperpolarizations of CA1 neurons (Greene and Haas, 1985).

Like the activation of $\mathrm{G}_{\mathrm{K}}$ by adenosine (Trussell and Jackson, 1987; Gerber et al., 1989), the adenosine-evoked formation of $\mathrm{IP}_{3}$ is mediated by a (perhaps the same) pertussis-sensitive G-protein (Arend et al., 1988). However, in their experiments on CA1 neurons pretreated with pertussis toxin, Spuler and Grafe (1989) found no suppression of anoxic (or hypoglycemic) hyperpolarizations, although adenosine applications were ineffective, and therefore concluded that adenosine could not be the essential mediator of these hyperpolarizations. One can suppose that, under some conditions, $\mathrm{G}_{\mathrm{K}(\mathrm{Ca})}$ (or some other $\mathrm{G}_{\mathrm{K}}$ ) may be activated by ATP depletion or that another factor is released, which can substitute for adenosine. Whether adenosine or such an alternative mechanism is predominant presumably will vary with the general metabolic state, as well as with local conditions at different sites in the brain. With regard to CA1 neurons, adenosine clearly accounts for a major portion of the hyperpolarizing effects of $\mathrm{CN}$.

The question remains whether this is mediated by the $G_{K}$ that is independent of second messengers (Trussell and Jackson, 1987; Gerber et al., 1989) or by the more complex route via $\mathrm{IP}_{3}$ and $\mathrm{G}_{\mathrm{K}(\mathrm{Ca})}$ suggested above. Our finding that Ba suppresses the effect of $\mathrm{CN}$ does not help to distinguish between these alternatives, because Ba blocks a variety of $\mathrm{K}$ currents, including $I_{\mathrm{AHP}}$ (Connor, 1979), $I_{\mathrm{M}}$ (Constanti et al., 1981), and $I_{\mathrm{K}}$ (Armstrong et al., 1982), as well as that elicited by adenosine (Trussell and Jackson, 1987; Gerber et al., 1989).

The present experiments show that Cs also attenuates the action of $\mathrm{CN}$, in agreement with its comparable effect on hypoxic hyperpolarizations (Leblond and Krnjević, 1989). Bearing in mind the well known block of the hippocampal Q current by Cs (Maccaferri et al., 1993), it is likely that the CN-evoked outward 
current is caused at least partly by adenosine-induced suppression of ongoing Q current. Indeed, the adenosine antagonist 8-SPT attenuated the effect of $\mathrm{CN}$ on $\mathrm{Q}$ current, in keeping with previous studies in which adenosine decreased Q-like inward currents (Pape, 1993; Rainnie et al., 1994). On the other hand, there is evidence that Cs depresses the M current (Coggan et al., 1994), which also may be enhanced by a $\mathrm{CN}$-induced rise in cytoplasmic [Ca] (Yu et al., 1994).

There is increasing interest in the effects of CN on CNS (Way, 1984; Jones et al., 1987; Baud et al., 1991; Dubinsky and Rothman, 1991; Krieglstein and Rischke, 1991; Brismar and Collins, 1993; Miller et al., 1993; Sturm et al., 1993). CN is a component of cigarette smoke, and it has been identified as a major cause of death from accidental smoke inhalation (Way, 1984; Jones et al., 1987; Baud et al., 1991). Adenosine attenuates neuronal damage induced by ischemia or CN (Krieglstein and Rischke, 1991; Sturm et al., 1993), presumably by reducing glutamate release (Patel et al., 1991, 1992; Cai and McCaslin, 1992). Therefore, adenosine release caused by $\mathrm{CN}$ has a neuroprotective effect in slices in vitro. However, $\mathrm{CN}$-induced adenosine release also suppresses CNS function, which in turn leads to loss of consciousness and then to loss of respiratory function. The present results point to adenosine as a crucial element in the intrinsic mechanism that links acute $\mathrm{CN}$ poisoning with almost immediate depression of CNS function.

\section{REFERENCES}

Aitken PG, Braitman DJ (1989) The effects of cyanide on neuronal and synaptic function in hippocampal slices. Neurotoxicology 10:239-247.

Andersen P, Sundberg SH, Sveen O, Swann JW, Wigstrom K (1980) Possible mechanisms for long-lasting potentiation of synaptic transmission in hippocampal slices from guinea-pigs. J Physiol (Lond) 320:463-482.

Arend LJ, Burnatowska-Hledin MA, Spielman WS (1988) Adenosine receptor-mediated calcium mobilization in cortical-collecting tubule cells. Am J Physiol 255:C581-C588.

Armstrong CM, Swenson RP, Taylor SR (1982) Block of squid axon K channels by internally and externally applied barium ions. J Gen Physiol 80:663-682.

Barcroft J (1931) The toxicity of atmospheres containing hydrocyanide acid gas. J Hyg 31:1-34.

Baud FJ, Barriot P, Toffis V, Riou B, Vicaut E, Lecarpentier Y, Bourdon R, Astier A, Bismuth C (1991) Elevated blood cyanide concentrations in victims of smoke inhalation. N Engl J Med 325:1761-1766.

Belousov A, Godfraind JM, Krnjević K (1995) Internal $\mathrm{Ca}^{2+}$ stores involved in anoxic responses of rat hippocampal neurons. J Physiol (Lond) 486:547-556.

Berne RM, Rubio R, Curnish RR (1974) Release of adenosine from ischemic brain. Circ Res 35:262-271.

Bernthal TB, Bronk DW, Cordero N, Gesell R (1928) The regulation of respiration. XVIII. The effects of low and high alveolar oxygen pressure and of sodium cyanide on the carotid and femoral flow of blood as studied with the continuous electrometric method. Am J Physiol 83:435-444.

Biscoe TJ, Duchen MR (1989) Electrophysiological responses of dissociated type I cells of the rabbit carotid body to cyanide. J Physiol (Lond) 413:447-468.

Biscoe TJ, Duchen MR (1990) Responses of type I cells dissociated from the rabbit carotid body to hypoxia. J Physiol (Lond) 428:39-59.

Blanton MG, Lo Turco JJ, Kriegstein AR (1989) Whole-cell recording from neurons in slices of reptilian and mammalian cerebral cortex. J Neurosci Methods 30:203-210.

Brismar T, Collins VP (1993) Effect of external cation concentration and metabolic inhibitors on membrane potential of human glial cells. J Physiol (Lond) 460:365-383.

Bruns RF, Daly JW, Snyder SH (1980) Adenosine receptors in brain membranes: binding of $N^{6}$-cyclohexyl $\left[{ }^{3} \mathrm{H}\right]$ adenosine and 1,3-diethyl8- $\left[{ }^{3} \mathrm{H}\right]$ phenylxanthine. Proc Natl Acad Sci USA 77:5547-5551.

Bruns RF, Fergus JH, Badger EW, Bristol JA, Santay LA, Hartman JD, Hays SJ, Huang CC (1987) Binding of $\mathrm{A}_{1}$-selective adenosine antago- nist 8-cyclopentyl-1,3-dipropylxanthine to rat brain membranes. Naunyn Schmiedebergs Arch Pharmacol 335:59-63.

Cai Z, McCaslin PP (1992) Selective effects of cyanide $(100 \mu \mathrm{M})$ on the excitatory amino acid-induced elevation of intracellular calcium levels in neuronal culture. Neurochem Res 17:803-808.

Coggan JS, Purnyn SL, Knoper SR, Kreulen DL (1994) Muscarinic inhibition of two potassium currents in guinea-pig prevertebral neurons: differentiation by extracellular cesium. Neuroscience 59:349-361.

Connor JA (1979) Calcium current in molluscan neurones: measurement under conditions which maximize its visibility. J Physiol (Lond) 286:41-60.

Constanti A, Adams PR, Brown DA (1981) Why do barium ions imitate acetylcholine? Brain Res 206:244-250.

Cummins TR, Donnelly DF, Haddad GG (1991) Effect of metabolic inhibition on the excitability of isolated hippocampal CA1 neurons: developmental aspects. J Neurophysiol 66:1471-1482.

Dixon M, Elliott KAC (1929) The effect of cyanide on respiration of animal tissues. Biochem J 23:812-830.

Dubinsky JM, Rothman SM (1991) Intracellular calcium concentrations during "chemical hypoxia" and excitotoxic neuronal injury. J Neurosci 11:2545-2551.

Duchen MR (1990) Effects of metabolic inhibition on the membrane properties of isolated mouse primary sensory neurons. J Physiol (Lond) 424:378-409.

Duchen MR, Biscoe TJ (1992) Relative mitochondrial membrane potential and $\left[\mathrm{Ca}^{2+}\right]_{\mathrm{i}}$ in type I cells isolated from the rabbit carotid body. J Physiol (Lond) 450:33-61.

Duchen MR, Valdeolmillos M, O’Neill SC, Eisner DA (1990) Effects of metabolic blockage on the regulation of intracellular calcium in dissociated mouse sensory neurons. J Physiol (Lond) 424:411-426.

Dunwiddie TV (1985) The physiological role of adenosine in the central nervous system. Int Rev Neurobiol 14:63-139.

Findlay I (1993) Sulphonylurea drugs no longer inhibit ATP-sensitive $\mathrm{K}^{+}$ channels during metabolic stress in cardiac muscle. J Pharmacol Exp Ther 226:456-467.

Fowler JC (1993) Purine release and inhibition of synaptic transmission during hypoxia and hypoglycaemia in rat hippocampal slices. Neurosci Lett 157:83-86.

Gerber U, Greene RW, Haas HL, Stevens DR (1989) Characterization of inhibition mediated by adenosine in the hippocampus of the rat in vitro. J Physiol (Lond) 417:567-578.

Gerwins P, Fredholm BB (1992) ATP and its metabolite adenosine act synergistically to mobilize intracellular calcium via the formation of inositol 1,4,5-trisphosphate in a smooth muscle cell line. J Biol Chem 267:16081-16087.

Godfraind JM, Kawamura H, Krnjević K, Pumain R (1971) Actions of dinitrophenol and some other metabolic inhibitors on cortical neurones. J Physiol (Lond) 215:199-222.

Greene RW, Haas HL (1985) Adenosine actions on CA1 pyramidal neurones in rat hippocampal slices. J Physiol (Lond) 366:119-127.

Greene RW, Haas HL (1991) The electrophysiology of adenosine in the mammalian central nervous system. Prog Neurobiol 36:329-341.

Haddad GG, Jiang C (1993) Mechanisms of anoxia-induced depolarization in brainstem neurons: in vitro current and voltage clamp studies in the adult rat. Brain Res 625:261-268.

Hochachka PW, Mommsen TP (1983) Protons and anaerobiosis. Science 219:1391-1397.

Isom GE, Way JL (1984) Effects of oxygen on the antagonism of cyanide intoxication: cytochrome oxidase, in vitro. Toxicol Appl Pharmacol 74:57-62.

Jones J, McMullen MJ, Dougherty J (1987) Toxic smoke inhalation: cyanide poisoning in fire victims. Am J Emerg Med 5:317-321.

Kaplin AI, Snyder SH, Linden DJ (1996) Reduced nicotinamide adenine dinucleotide-selective stimulation of inositol 1,4,5-trisphosphate receptors mediates hypoxic mobilization of calcium. J Neurosci 16:2001-2011.

Keilin D (1930) Cytochrome and intracellular oxidase. Proc R Soc Lond [Biol] 106:418-444.

Kohl C, Linck B, Schmitz W, Scholz H, Scholz J, Tóth M (1990) Effects of carbachol and (-)- $\mathrm{N}^{6}$-phenylisopropyladenosine on myocardial inositol phosphate content and force of contraction. $\mathrm{Br} \mathrm{J}$ Pharmacol 101:829-834.

Krieglstein J, Rischke R (1991) Vinpocetine increases the neuroprotective effect of adenosine in vitro. Eur J Pharmacol 19:7-10.

Kurbat JM, Buchanan RJ, Wulff SC, Yoon K-W (1993) Cyanide- 
mediated adenosine release from rat hippocampal neurons. Soc Neurosci Abstr 19:1661.

Latha MV, Borowitz JL, Yim GK, Kanthasamy A, Isom GE (1994) Plasma membrane hyperpolarization by cyanide in chromaffin cells: role of potassium channels. Arch Toxicol 68:370-374.

Leblond J, Krnjević K (1989) Hypoxic changes in hippocampal neurons. J Neurophysiol 62:1-14.

Lipton P, Whittingham TS (1982) Reduced ATP concentration as a basis for synaptic transmission failure during hypoxia in the in vitro guinea-pig hippocampus. J Physiol (Lond) 325:51-65.

Maccaferri G, Mangoni M, Lazzari A, DiFrancesco D (1993) Properties of the hyperpolarization-activated current in rat hippocampal CA1 pyramidal cells. J Neurophysiol 69:2129-2136.

Maire JC, Medilanski J, Straub RW (1984) Release of adenosine, inosine, and hypoxanthine from rabbit non-myelinated nerve fibres at rest and during activity. J Physiol (Lond) 357:67-77.

Miller AL, Morales E, Leblanc NR, Cole WC (1993) Metabolic inhibition enhances $\mathrm{Ca}^{2+}$-activated $\mathrm{K}^{+}$current in smooth muscle cells of rabbit portal vein. Am J Physiol 256:H2184-H2195.

Mogul DJ, Adams ME, Fox AP (1993) Differential activation of adenosine receptors decreases $\mathrm{N}$-type but potentiates $\mathrm{P}$-type $\mathrm{Ca}^{2+}$ current in hippocampal CA3 neurons. Neuron 10:327-334.

Morris ME, Leblond J, Agopyan N, Krnjević K (1991) Temperature dependence of extracellular ionic changes evoked by anoxia in hippocampal slices. J Neurophysiol 65:157-167.

Murphy KP, Greenfield SA (1991) ATP-sensitive potassium channels counteract anoxia in neurons of the substantia nigra. Exp Brain Res 84:355-358.

Nicholls DG (1989) Release of glutamate, aspartate, and $\gamma$-aminobutyric acid from isolated nerve terminals. J Neurochem 52:331-341.

Nichols CG, Lederer WJ (1990) The regulation of ATP-sensitive $\mathrm{K}^{+}$ channel activity in intact and permeabilized rat ventricular myocytes. J Physiol (Lond) 423:91-110.

Noma A (1983) ATP-regulated single K channels in cardiac muscle. Nature 305:147-148.

Pape H-C (1993) Adenosine promotes burst activity in guinea-pig geniculocortical neurons through two different ionic mechanisms. J Physiol (Lond) 447:729-753.

Patel MN, Ardelt BK, Yim GK, Isom GE (1991) Cyanide induces $\mathrm{Ca}^{2+}$. dependent and -independent release of glutamate from mouse brain slices. Neurosci Lett 131:42-44.

Patel MN, Yim GK, Isom GE (1992) Blockage of $N$-methyl-D-aspartate receptors prevents cyanide-induced neuronal injury in primary hippocampal cultures. Toxicol Appl Pharmacol 115:124-129.

Perkins KL, Wong RKS (1995) Intracellular QX-314 blocks the hyperpolarization-activated inward current $I_{\mathrm{Q}}$ in hippocampal CA1 pyramidal cells. J Neurophysiol 73:911-915.

Phillis JW, Wu PH (1981) The role of adenosine and its nucleotides in central nervous system. Prog Neurobiol 16:187-239.

Phillis JW, O'Regan MH, Walter GA (1989) Effects of two nucleoside transport inhibitors, dipyridamole and soluflazine, on purine release from the rat cerebral cortex. Brain Res 481:309-316.

Proctor WR, Dunwiddie TV (1987) Pre- and postsynaptic actions of adenosine in the in vitro rat hippocampus. Brain Res 426:187-190.

Rainnie DR, Grunze HC, McCarley RW, Greene RW (1994) Adenosine inhibition of mesopontine cholinergic neurons: implications for EEG arousal. Science 263:689-692.

Richardt G, Waas W, Kranzhöfer R, Mayer E, Schömig A (1987) Adenosine inhibits exocytotic release of endogenous noradrenaline in rat heart: a protective mechanism in early myocardial ischemia. Circ Res 61:117-123.

Richardt G, Blessing R, Schömig A (1994) Cardiac noradrenaline release accelerates adenosine formation in the ischemic rat heart: role of neuronal noradrenaline carrier and adrenergic receptors. J Mol Cell Cardiol 26:1321-1328.

Scholz KP, Miller RJ (1991) Analysis of adenosine actions on $\mathrm{Ca}^{2+}$ currents and synaptic transmission in cultured rat hippocampal pyramidal neurones. J Physiol (Lond) 435:373-393.

Schwanstecher C, Panten U (1993) Tolbutamide- and diazoxide-sensitive $\mathrm{K}^{+}$channels in neurons of substantia nigra pars reticulata. Naunyn Schmiedebergs Arch Pharmacol 348:113-117.

Snyder SH (1985) Adenosine as a neuromodulator. Annu Rev Neurosci 8:103-124.

Spuler A, Grafe P (1989) Adenosine, "pertussis-sensitive" G-proteins, and $\mathrm{K}^{+}$conductance in central mammalian neurones under energy deprivation. Neurosci Lett 98:280-284.

Sturm CD, Frisella WA, Yoon KW (1993) Attenuation of potassium cyanide-mediated neuronal cell death by adenosine. J Neurosurg 79:111-115.

Sun M-K, Reis DJ (1994) Hypoxia-activated $\mathrm{Ca}^{2+}$ currents in pacemaker neurones of rat rostral ventrolateral medulla in vitro. J Physiol (Lond) 476:101-116.

Thampy KG, Barnes Jr EM (1983) Adenosine transport by primary cultures of neurons from chick embryo brain. J Neurochem 40:874-879.

Trapp S, Ballanyi K (1995) $\mathrm{K}_{\mathrm{ATP}}$ channel mediation of anoxia-induced outward current in rat dorsal vagal neurons in vitro. J Physiol (Lond) 487:37-50.

Trussell LO, Jackson MB (1987) Dependence of an adenosine-activated potassium current on a GTP-binding protein in mammalian central neurons. J Neurosci 7:3306-3316.

Van Wylen DGL, Park TS, Rubio R, Berne RM (1986) Increases in cerebrospinal fluid adenosine concentration during hypoxia, local potassium infusion, and ischemia. J Cereb Blood Flow Metab 6:522-528.

Way JL (1984) Cyanide intoxication and its mechanism of antagonism. Annu Rev Pharmacol Toxicol 24:451-481.

Wu L-G, Saggau P (1994) Adenosine inhibits evoked synaptic transmission primarily by reducing presynaptic calcium influx in area CA1 of hippocampus. Neuron 12:1139-1148.

Young JD, Jarvis SM (1983) Nucleoside transport in animal cells. Biosci Rep 3:309-322.

Yu SP, O’Malley MD, Adams PR (1994) Regulation of M current by intracellular calcium in bullfrog sympathetic ganglion neurons. J Neurosci 14:3487-3499.

Zhang J, Krnjević K (1993) Whole-cell recording of anoxic effects on hippocampal neurons in slices. J Neurophysiol 69:118-127.

Zhu PJ, Krnjević K (1993) Adenosine release is a major cause of failure of synaptic transmission during hypoglycaemia in rat hippocampal slices. Neurosci Lett 155:128-131.

Zhu PJ, Krnjević K (1994) Endogenous adenosine deaminase does not modulate synaptic transmission in rat hippocampal slices under normoxic or hypoxic condition. Neuroscience 63:489-497.

Zhu PJ, Krnjević K (1995) Adenosine mediates cyanide (CN)-induced inhibition of hyperpolarization-activated inward current in whole-cell recorded hippocampal neurons in slices. Soc Neurosci Abstr 21:589.

Zhu PJ, Krnjević K (1997) Endogenous adenosine on membrane properties of CA1 neurons in rat hippocampal slices during normoxic and hypoxia. Neuropharmacology, in press. 